\title{
Assessing the uniaxial compressive strength and tangent Young's modulus of basalt rock using the Leeb rebound hardness test
}

\author{
H. Aldeeky ${ }^{\mathrm{a}} \bowtie$, O. Al Hattamleh ${ }^{\mathrm{a}}$, S. Rababah ${ }^{\mathrm{b}}$ \\ a. Civil Engineering Department, College of Engineering, The Hashemite University, (Zarqa, Jordan) \\ b. Civil Engineering Department, College of Engineering, Jordan University of Science \&Technology, (Irbid, Jordan) \\ \: aldeeky@hu.edu.jo \\ Received 12 November 2019 \\ Accepted 6 April 2020 \\ Available on line 25 September 2020
}

\begin{abstract}
Basalt was used as an ornamental stone in many historic and ancient cities in Jordan. Measuring the uniaxial compressive strength (UCS) and the tangent Young's modulus $\left(\mathrm{E}_{\mathrm{t}}\right)$ in the laboratory requires premium quality specimens with special core dimensions. This research focuses on correlations both UCS and $\mathrm{E}_{\mathrm{t}}$ with Leeb Rebound Hardness Test (LRH). In the laboratory, UCS, $\mathrm{E}_{\mathrm{t}}$, and LRH were performed on 90 core samples extracted from 30 different rock boulders collected from the neighboring area of Umm al-Jimal, a historic city in northeastern Jordan. A strong power correlation with $\left(\mathrm{R}^{2}=0.888\right.$, $\left.\mathrm{RMSE}=5.464\right)$ was found between non-destructive LRH value and UCS. On the other hand, a moderately strong linear regression with $\left(\mathrm{R}^{2}=0.792, \mathrm{RMSE}=4.661\right)$ was found between $\mathrm{E}_{\mathrm{t}}$ and $\mathrm{LRH}$. In conclusion, non-destructive LRHs can be used as indictors for evaluating both UCS and $\mathrm{E}_{\mathrm{t}}$ during the restoration of the historic city Umm al-Jimal and the rehabilitation of other existing structures.
\end{abstract}

KEYWORDS: Ornamental stones; Mechanical properties; Compressive strength; Modulus of elasticity; Petrography.

Citation/Citar como: Aldeeky, H.; Al Hattamleh, O.; Radabah, S. (2020) Assessing the uniaxial compressive strength and tangent Young's modulus of basalt rock using the Leeb rebound hardness test. Mater. Construcc. 70 [340], e230 https://doi.org/10.3989/mc.2020.15119

RESUMEN: Evaluación de la resistencia a compression uniaxial y de la tangente del módulo de Young de rocas basálticas utilizando la prueba de dureza de rebote Leeb. El basalto como piedra ornamental se usó en muchas ciudades históricas de Jordania. La medición de la resistencia a compresión uniaxial (UCS) y de la tangente del módulo de Young (Et) en el laboratorio requiere muestras de calidad superior con un núcleo de dimensión especial. Esta investigación se centra en correlacionar la UCS y el Et con la prueba de dureza de rebote Leeb (LRH). Se realizaron ensayos de laboratorio de UCS, Et y LRH en noventa muestras de núcleos que se extrajeron de treinta rocas diferentes recogidas en el área vecina de la ciudad histórica de Um-Al Jimal, al noreste de Jordania. Se encontró una fuerte correlación $\left(\mathrm{R}^{2}=0.888, \mathrm{RMSE}=5.464\right)$ entre el valor de LRH no destructivo y la UCS. Por otro lado, se encontró una regresión lineal moderada fuerte $\left(R^{2}=0.792, R M S E=4.661\right)$ entre Et y LRH. En conclusión, la LRH no destructiva puede emplearse como indicador para evaluar tanto UCS como Et durante la restauración de la ciudad histórica (Um-Al Jimal) y otras rehabilitaciones de estructuras existentes.

PALABRAS CLAVE: Piedras ornamentales; Propiedades mecánicas; Resistencia a compresión; Módulo de elasticidad; Petrografía.

ORCID ID: H. Aldeeky (https://orcid.org/0000-0003-0468-1678); O. Al Hattamleh (https://orcid.org/0000-0001-9039-2850); S. Rababah (https://orcid.org/0000-0002-4370-9007)

Copyright: (C) 2020 CSIC. This is an open-access article distributed under the terms of the Creative Commons Attribution 4.0 International (CC BY 4.0) License. 


\section{INTRODUCTION}

Restoration of historic buildings and monuments is a challenging task. In most cases, destructive tests are not allowed, therefore, non-destructive tests to evaluate mechanical behavior are required. Uniaxial compressive strength (UCS) and tangent Young's modulus $\left(E_{t}\right)$ are the main input parameters of the mechanical behavior of rock, especially in ascertaining rock shear strength, rock mass rating (RMR), classification, and earth structure design such as foundation and tunneling (1-6).

Conducting a UCS test in the laboratory according to ISRM (7) and ASTM D7012 (8) requires a specified core of premium quality with certain dimensions. Sometimes a core sample is not possible, especially in foliated, soft, weathered, and fractured rock, or it is not allowed in historic buildings. In addition, the UCS test is a destructive, expensive, and time-consuming method as reported by many researchers (9-14). For these reasons, the correlation between UCS and $\mathrm{E}_{\mathrm{t}}$ with the non-destructive or simple tests that require no sample preparation is more desired (15-17). Different empirical models have been developed to estimate the UCS and $\mathrm{E}_{\mathrm{t}}$ depending on simple or non-destructive tests. These tests include porosity, dry density, Brazilian tensile strength test, point load, pulse velocity, slake durability index, Schmidt hammer hardness, Shore scleroscope hardness, and Brinell hardness tests (18-24).

The Schmidt hammer procedure is a nondestructive and rapid test of hardness. Therefore, many researchers have developed numerous correlations between Schmidt hammer hardness, either linear or non-linear, and UCS and $\mathrm{E}_{\mathrm{t}}$ for diverse types of rocks (25-35).

An Equotip hardness tester also was recommended for use in geological and rock mechanical applications (36, 37). Hack et al. (36) used Equotip hardness type D to evaluate wall strength discontinuity. For this purpose, they used cubic samples with a $20 \mathrm{~cm}$ edge side from different rock types (granite, limestone, and sandstone). They found that the influence of layer thickness on Equotip hardness is very small compared to Schmidt hammer hardness and that Equotip is better at reflecting wall discontinuity. Also, they concluded that rock strength and surface roughness affected the Equotip hardness value more than rock density and elastic modulus. Verwaal and Mulder (38) studied the possibility of estimating UCS from the Equotip L-value test and the effect of size and roughness on Equotip L-value. Based on limestone cores with different diameters and lengths, they concluded that Equotip L-value increases with the increase in both diameter and length. On the other hand, they found the surface roughness presents no major influence on Equotip L-value. Meulenkamp and Grima (39) used neural networks to correlate UCS with Equotip L-value, porosity, density, rock texture, and rock type for sandstone, limestone, dolomite, granite, and granodiorites.

Okawa et al. (40) found that both surface roughness and curvature have no influence on Equotip L-value. Kawasaki et al. (41) conducted an Equotip hardness test on core rock samples for many rock types (sandstone, greenschist, hornfels, granite, shale), recommending a linear relationship between Equotip L-values and USC. This recommended equation depends on rock type and Equotip L-values. Aoki and Matsukura (37) found a good correlation between Equotip L-values, porosity, and USC for different rock types (tuff, sandstone, granite, gabbro, limestone). Using hybrid dynamic hardness (HDH) to investigate the effect of the test procedure on the UCS prediction on carbonate rocks, Ylimaz (42) found that the test procedure based on single impacts is more suitable for UCS prediction. Also, based on cubic samples with edge dimensions of $5,9,11,13$, and $15 \mathrm{~cm}$, he concluded that there is no size effect on mean rebound values. Lee et al. (43) utilized Leeb rebound hardness to study the relation between Leeb rebound hardness number (RHN) and UCS for 24 shale samples; they found that UCS varies exponentially with RHN.

Siri et al. (44) presented a nonlinear relation between type D Leeb Hardness values (LRH) and UCS for sandstone rocks. They recommended that there is no size effect if the sample volume is greater than $100 \mathrm{~cm}^{3}$. Corkum et al. (45) studied the correlation between LRH test values and UCS for various rock types. Based on 213 sedimentary, 40 metamorphic, and 58 igneous rocks, they found a nonlinear power function between LRH and USC. They concluded that there is no scale effect on LRH value if the specimen's volume is at least $90 \mathrm{~cm}^{3}$ for block or irregular block specimens, or with about $\mathrm{L} / \mathrm{D}>0.4$ for core specimens. Kovler et al. (46) used static Schmidt rebound test and dynamic LRH test to evaluate concrete compressive strength with different water-cement ratios. They found that the LRH could be applied in predicting concrete compressive strength within a $10 \%$ margin of error for all water-cement ratios. On the other hand, they reported that the Schmidt rebound test can be considered a semi-destructive method since they found a significant strength reduction (on average by 10.5 MPa) after applying Schmidt hammer impact on specimens, while there was no damage in the concrete sample after applying LRH test. Yilmaz and Goktan (47) used two types of non-destructive hardness tests (L-type Schmidt hammer and the Equotip 3 hardness tester with D-probe) to evaluate UCS. They used 11 rock core samples with a diameter of $54 \mathrm{~mm}$ for basalt, limestone, andesite, tuff, travertine, and marble rocks. They proposed a power relation between Equotip hardness, Schmidt 
hammer, and USC. Also, they found a good prediction accuracy with $\mathrm{R}^{2}=0.87$ between USC and Equotip hardness and an accuracy ratio $=0.60 \mathrm{com}-$ pared to Schmidt hammer hardness.

To study the effect of core holder type on LRH, Yilmaz and Goktan (48) used two different holders, a V-shape holder and an arch-shape holder. They found that the difference between LRH magnitudes in both holders is small and varies from one rock to another. Celik and Cobanoglu (49) predicted the physical and mechanical properties of different rock type, igneous, sedimentary, and metamorphic rock, using three types of non-destructive hardness tests. Based on their results, they concluded that Leeb hardness is more accurate in predicting mechanical and physical rock properties compared with shore scleroscope and Schmidt hammer type L.

Based on his results using Equotip (type D) hardness test to evaluate the mechanical properties of volcanic tuff building stone in Turkey, Yüksek (50) found that there is a moderately good exponential correlation between LRH with UCS and dry unit weight; also, he found a fairly linear correlation with porosity and water absorption. Desarnaud et al. (51) studied the effect of sample size, moisture content, and surface roughness on the Equotip rebound hardness of sandstone rock samples. They recorded that Equotip rebound hardness is reduced by $26 \%$ in the saturated cases compared with the dry cases and also that sample size has a significant effect on Equotip rebound hardness compared with surface roughness. Table 1 summarizes some of the previous correlations between UCS and LRH.

LRHT was adopted in this research because it is a portable device, non-destructive, and a simple test that has a high testing rate with each test taking about 2 seconds. In addition to being low cost and suitable for hard and soft materials, it measures in any direction and can be directly converted to Rockwell, Brinell, and Vickers hardness. Few researchers have attempted to find a relationship between UCS and $\mathrm{E}_{\mathrm{t}}$ with LRHT.

The aim of this research was to acquire a correlation using the LRHT to predict the UCS and the $E_{t}$ of basalt rocks in Harrat al-Sham in eastern Jordan. The developed model might be useful in the restoration of the historic city Umm al-Jimal and in the rehabilitation of other existing structures. To achieve this target, the UCS and $\mathrm{E}_{\mathrm{t}}$ along with LRHT of basalt samples collected from the neighboring area of Umm al-Jimal were determined in the laboratory, then the power and linear relationship between UCS and $\mathrm{E}_{\mathrm{t}}$ with LRHT test was established respectively.

TABLE 1. Some previous correlations between UCS and LRH.

\begin{tabular}{|c|c|c|c|}
\hline References & Lithology & Correlations & $\mathbf{R}^{2}$ \\
\hline Aoki and Matsukura (37) & $\begin{array}{l}\text { tuff, sandstone, granite, andesite, } \\
\text { gabbro, and limestone }\end{array}$ & $\begin{array}{l}\mathrm{UCS}=0.079 \operatorname{EXP}(-0.039 \mathrm{n}) \\
(\mathrm{LRH} 1.1)\end{array}$ & 0.88 \\
\hline Verwaal and Mulder (38) & $\begin{array}{l}\text { limestone, granite, sandstone and } \\
\text { man-made gypsum }\end{array}$ & $\mathrm{UCS}=8 \times 10^{-6}(\mathrm{LRH})^{2.5}$ & 0.77 \\
\hline Meulenkamp and Grima (39) & $\begin{array}{l}\text { limestone, granite, sandstone, } \\
\text { dolostone and granodiorite }\end{array}$ & $\mathrm{UCS}=1.75 \times 10^{-9}(\mathrm{LRH})^{3.8}$ & 0.806 \\
\hline Lee et al. (43) & shale & $\mathrm{UCS}=2.3007 \mathrm{EXP}(0.0057 \mathrm{LRH})$ & 0.823 \\
\hline ASiri et al. (44) & sandstone & $\mathrm{UCS}=2.548 \mathrm{EXP}(0.00537 \mathrm{LRH})$ & 0.72 \\
\hline Corkum et al. (45) & igneous & $\mathrm{UCS}=3.0 \times 10^{-6}(\mathrm{LRH})^{2.64}$ & 0.65 \\
\hline Corkum et al. (45) & Sandstone & $\mathrm{UCS}=0.9 \times 10^{-6}(\mathrm{LRH})^{2.84}$ & 0.75 \\
\hline Corkum et al. (45) & Sedimentary & $\mathrm{UCS}=0.1 \times 10^{-6}(\mathrm{LRH})^{3.18}$ & 0.71 \\
\hline Corkum et al. (45) & Metamorphic & $\mathrm{UCS}=0.3 \times 10^{-6}(\mathrm{LRH})^{2.98}$ & 0.75 \\
\hline Kovler et al. (46) & Concrete & $\mathrm{UCS}=0.18 \mathrm{LRH}-11$ & 0.92 \\
\hline Yilmaz and Goktan(47) & $\begin{array}{l}\text { basalt, limestone, andesite, tuff, } \\
\text { travertine and marble }\end{array}$ & $\mathrm{UCS}=2.0 \times 10^{-8}(\mathrm{LRH})^{3.3492}$ & 0.87 \\
\hline Yilmaz and Goktan (48) & 16 different rock samples & $\mathrm{UCS}=0.229 \mathrm{LRH}-84.242$ & 0.87 \\
\hline Celik and Cobanoglu (49) & $\begin{array}{l}\text { Travertine, limestone dolomite, Marble, } \\
\text { schist, granite, syenite andesite gabbro, } \\
\text { dunite, tuff, and ignimbrite }\end{array}$ & $\mathrm{UCS}=7.0 \times 10^{-7}(\mathrm{LRH})^{2.875}$ & 0.80 \\
\hline Yüksek(50) & Volcanic tuff & $\mathrm{UCS}=2.359 \mathrm{EXP}(0.0044 \mathrm{LRH})$ & 0.657 \\
\hline Kawasaki et al. (52) & shale & $\mathrm{UCS}=156+0.309 \mathrm{LRH}$ & 0.818 \\
\hline Kawasaki et al. (52) & granite & $\mathrm{UCS}=271-0.38 \mathrm{LRH}$ & 0.356 \\
\hline Kawasaki et al. (52 ) & hornfels & $\mathrm{UCS}=64.6+0.122 \mathrm{LRH}$ & 0.339 \\
\hline ASiri et al. (53) & igneous rock & $\mathrm{UCS}=9.70 \times 10^{-5}(\mathrm{LRH})^{2.14}$ & 0.65 \\
\hline
\end{tabular}




\section{BASALT IN JORDAN AND STUDY AREA}

Basalt rock covers about $11 \%$ of Jordan's area $(54,55)$. As explained in Figure 1, basalt rock covers about $11400 \mathrm{~km}^{2}$, in both Harrat al-Shamin in the northeast and Harrat Irbid in the northwestern part of Jordan $(57,58)$. As a building stone, basalt was used in many historic and ancient cities in Jordan such as Umm Qais located to the north of Jordan, Qasr al-Mashta and Umm al-Jimal (east of Al-Mafraq), Qasr al-Hallabat and Qastal (south of Jordan), and Qasr al-Azraq (59), as presented in Figure 2. During the Roman period, basalt stones were used as road pavement. Nowadays, basalt is used as aggregates, dimension stone, curbstone, paving stone, and in industrial applications due to it is wide availability in Jordan where basalt stone constitutes about $15 \%$ of the country's economic rocks (60-62).

Thirty basalt boulders with dimensions of approximately $30 \times 30 \times 50 \mathrm{~cm}$ were collected from the neighboring area of the historic Umm al-Jimal village located in the northeast of Jordan; the study
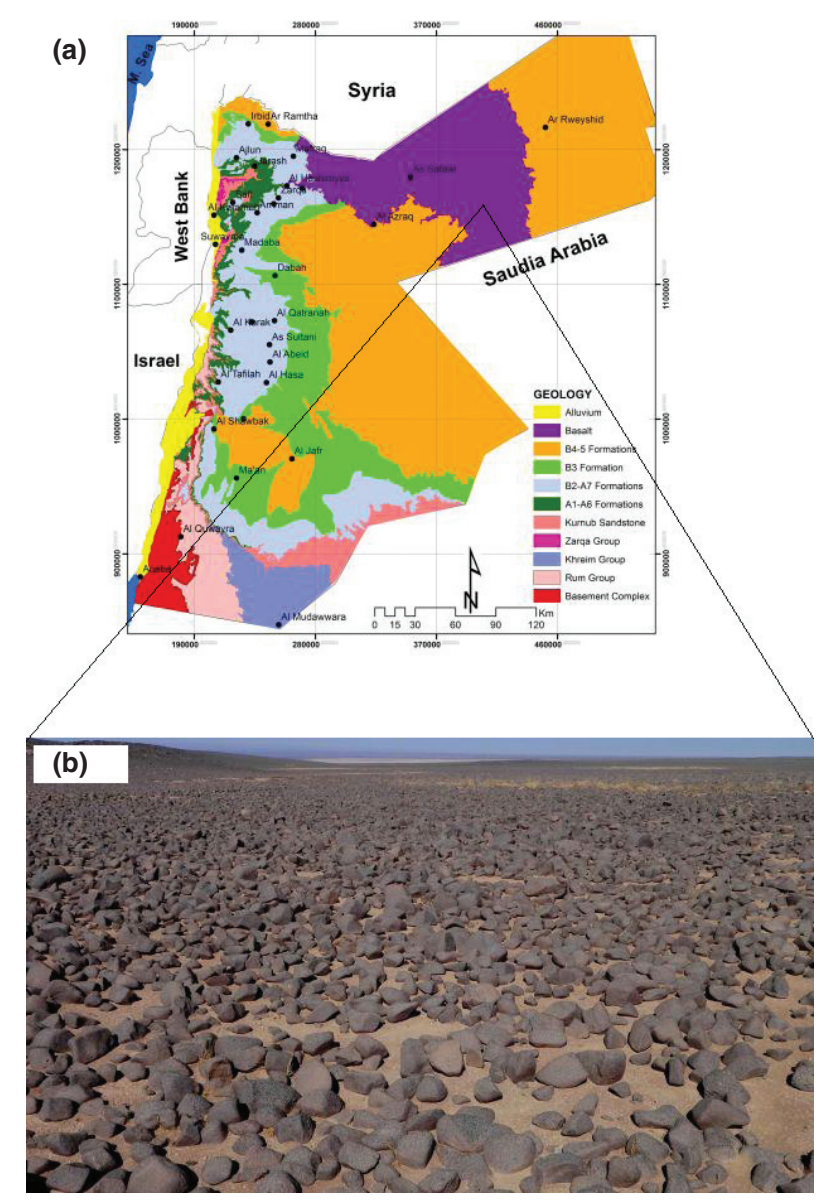

FIGURE 1. (a) Location of basalt rock distribution in Jordan; modified from Al Kuisi et al. (56); (b) Basalt boulders in Harrat al-Sham (northeast of Jordan). area is located at latitude $32^{\circ} 19^{\prime} 36^{\prime \prime} \mathrm{N}$, and longitude $36^{\circ} 22^{\prime} 11^{\prime \prime}$ E (Figure 3).

\section{LEEB REBOUND HARDNESS TEST (LRH)}

In 1975, Leeb and Brandestini developed LRH, a portable nondestructive device with dynamic impact energy, for the Proceq SA Company in Switzerland to test the hardness of metals (63). The Leeb rebound hardness was calculated based on the following Equation [1]:

$$
\mathrm{LRH}=(\mathrm{Vr} / \mathrm{Vi}) \times 1000
$$

Where LRH: Leeb rebound hardness, Vr: impact speed, Vi: rebound speed.

LRH type D is a non-destructive test with low impact energy of about $11 \mathrm{~N} \mathrm{~mm}$, about 1/200 of the rebound Schmidt hammer test type $\mathrm{N}$ and 1/66 type L (64). Because it is low energy, this test is suitable for soft and thin layers. LRH can be repeated on the same spot without affecting the rock sample, compared with Schmidt hammer as recommended by Aoki and Matsukura (65). Table 2 summarizes a compression between Schmidt hammer type $\mathrm{N}$ and LRH type D.

\section{MATERIALS AND METHODS}

Thirty basalt boulders with dimensions of approximately $30 \times 30 \times 50 \mathrm{~cm}$ were collected from the neighboring area of Umm al-Jimal in northeastern Jordan. Selected boulder samples had no joints or fractures. From each boulder, three NX cylindrical rock core specimens with a diameter of $64.0 \mathrm{~mm}$ and length of $130.0 \mathrm{~mm}$ were prepared according to ASTM D4543 (66) and ISRM (7). After coring, samples were cut to a 2:1 ratio of length to diameter. The specimens were polished using a suitable machine to ensure a smooth surface.

The ASTM A956 (67) testing procedure for LRH is standard for steel products only; therefore, the ASTM is not applicable for rock specimens. Since there is no international standard test procedure for LRH on rock materials regarding test procedure, data evaluation, or specimen preparation, a single impact method was adopted as recommended by Daniels et al. (68) and Corkum et al. (45). Using this method, an air-dry core specimen was fixed, and the device was pressed perpendicular to the specimen surface (Figure 4). Twelve impact values were conducted on each core specimen, then the average of the remaining 10 values was recorded as the LRH value after excluding the maximum and minimum value.

UCS and $\mathrm{E}_{\mathrm{t}}$ tests were performed according to ISRM (7) and ASTM D 7012 (69) using a computerized MTS compression machine (Matest-Italy) with 

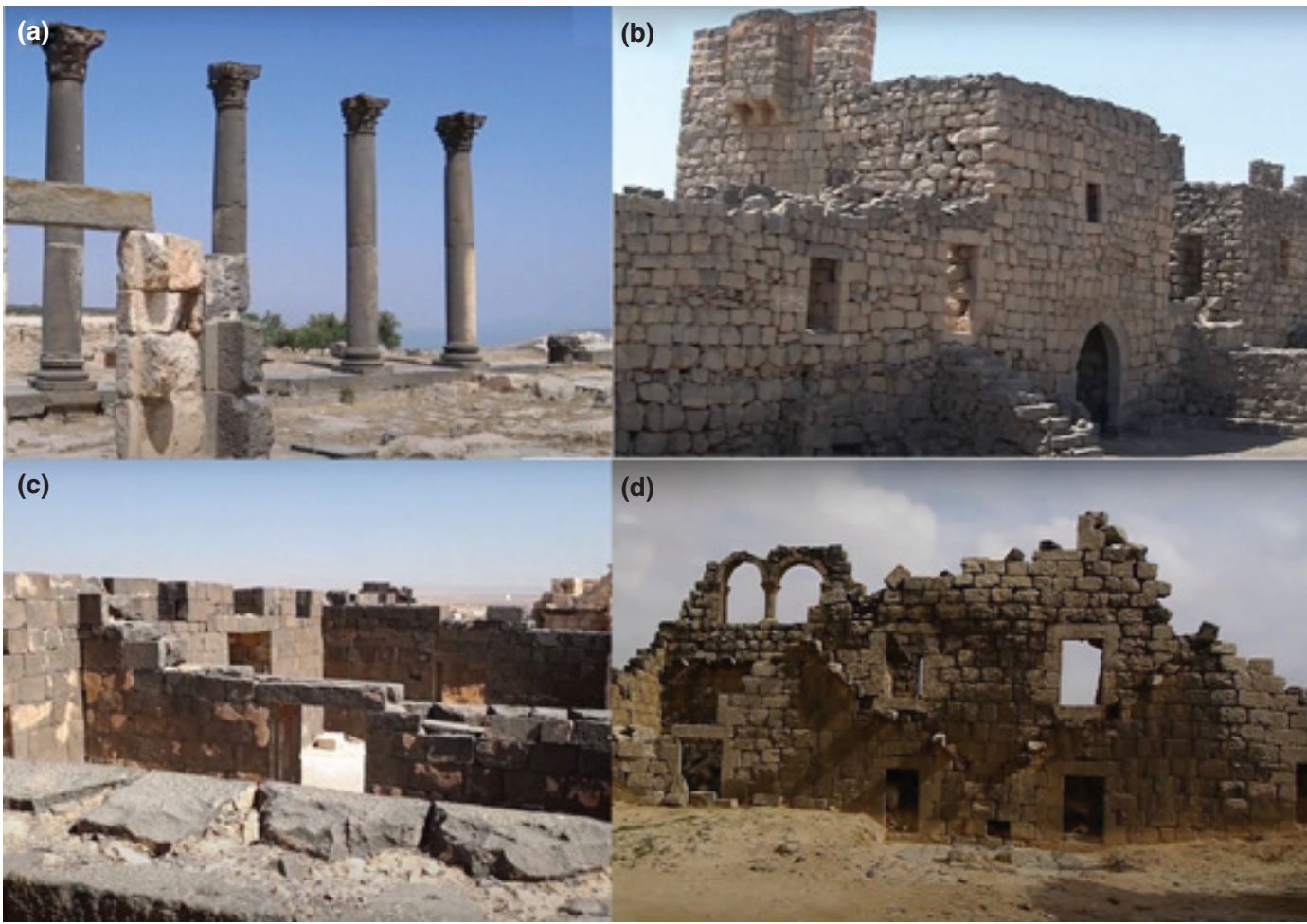

FIGURE 2. Pictures of basalt historic buildings in Jordan. (a) Umm Qais located to the north of Jordan. (b) Qasr Al-Azraq. (c) Qaser al-Hallabat and Qastal. (d) Umm al-Jimal (east of Al-Mafraq).

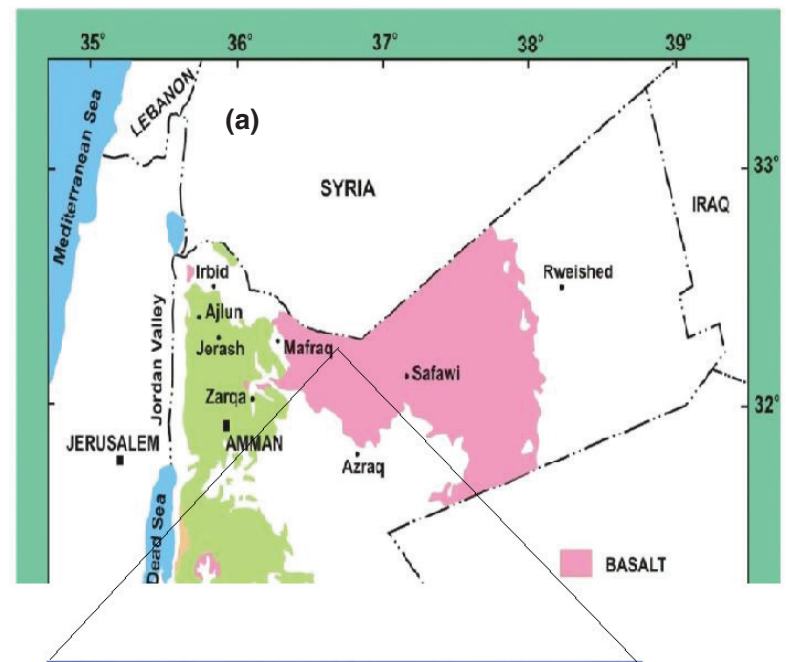

(b)

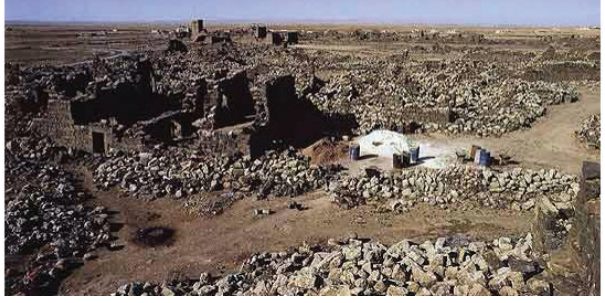

FIgURE 3. (a) Study area. (b) Historic Umm al-Jimal village. a maximum compression static load of $2000 \mathrm{kN}$. A stress rate of $0.5 \mathrm{MPa} / \mathrm{s}$ was applied to reach failure within 5-10 min. The reported UCS was equal to the failure load divided by the cross-sectional area of the cylindrical specimen. The tests were conducted on the three prepared cylindrical specimens of each boulder sample and the average was reported.

$\mathrm{E}_{\mathrm{t}}$ is a key factor in evaluating rock deformation. $E_{t}$ can be determined from the stress-strain curve analysis, where $E_{t}$ is the slope of the tangent of the stress-strain curve at point represent $50 \%$ of UCS as described by Bejarbaneh et al. (70) and Malkowskia et al. (71).

A Phillips X-ray florescence (XRF) Majex Pw-242 model, available from the Water, Environment, and Arid Regions Research Center at Al al-Bayt University in Jordan, was adopted to determine the major elements analyzed using fused glass discs. Of the basalt samples. A basalt sample was dried then crushed until it reached a size of $10 \mathrm{~mm}$. The sample was then ground into powder using a ball mill with a tungsten carbide barrel at 400 RPM until the sample reached a size of about $0.075 \mathrm{~mm}$. Two grams of the powder sample were mixed with $8 \mathrm{~g}$ of lithium tetraborate then fused in platinum crucibles over gas burners at $1000{ }^{\circ} \mathrm{C}$ for one hour, then the melted sample poured in a mold to create glass disks. The test results were analyzed using GEOS 
TABle 2. Comparison between Leeb Hardness Tester Type D and Schmidt Hammer Tester type N.

\begin{tabular}{lll}
\hline Hardness tester & Leeb Hardness Tester type D & Schmidt Hammer type N \\
\hline Impact energy $(\mathrm{Nm})(64)$ & 0.011 & 2.207 \\
Length $(\mathrm{cm})$ & 15.5 & 30 \\
Weight $(\mathrm{kg})$ & 0.166 & 1.52 \\
Impact direction (42) & $360^{\circ}$ & $90^{\circ}$ \\
Minimum thickness $(\mathrm{mm})$ & 5 & 100 \\
UCS (MPa) range & $3-285$ & $10-70$ \\
Impact plunger diameter $(\mathrm{cm})$ & 0.5 & 1.5 \\
Type of energy & Dynamic test & Static test \\
Layer thickness (65) & Suitable for a thin layer & Not suitable for a thin layer \\
Effect of water content $(64,65)$ & Slightly not affected & Significantly affected \\
Standard test method & No standard for rock & ISRM (7) \\
\hline
\end{tabular}

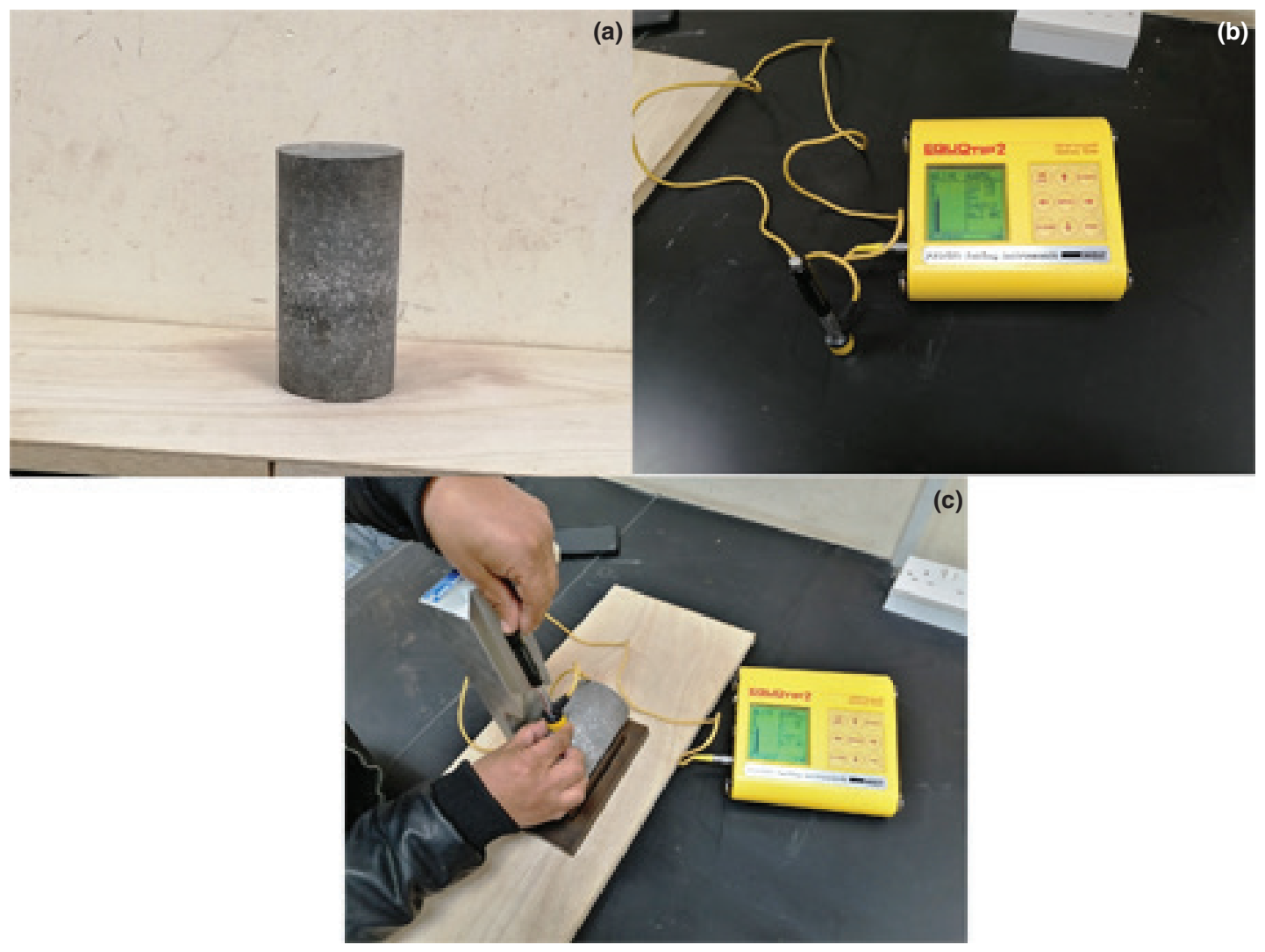

FIgure 4. (a) Core specimen. (b) Equo tip 2 devices. (c) Core specimen with holder under test.

software calibration to international geological rock standards. The contents of the major oxides of $\mathrm{Si}$, $\mathrm{Ti}, \mathrm{Al}, \mathrm{Fe}, \mathrm{Mg}, \mathrm{Mn}, \mathrm{Ca}, \mathrm{Na}$, and $\mathrm{K}$ were analyzed. Loss on ignition was determined first by drying the powder sample at $110{ }^{\circ} \mathrm{C}$ for eight hours, then weighted before and after ignition at $1000{ }^{\circ} \mathrm{C}$. The sample preparation and test were conducted according to ASTM E1621 (72).
An X-ray diffractometer (XRD) type XRD-7000 (CuK $\alpha 1$ radiation, $\lambda=1.54060 \AA)$, using $99 \%$ silicon powder and 325 mesh $(0.044 \mathrm{~mm})$ for calibration was available through the geology department at Hashemite University. A randomly oriented powder mount was adopted in this test. The mounts are typically X-rayed between the angles of 5 and 65 degrees 2 theta using copper $\mathrm{K}$ alpha radiation at 
a scanning rate of 2 degrees per minute. First, the sample was crushed and powdered to reach a size $0.040 \mathrm{~mm}$, then $1 \mathrm{~g}$ of the powder was used on the sample holder. The sample preparation and test were conducted according to "A Laboratory Manual for X-Ray Powder Diffraction" (73).

A thin slab of a basalt core sample about $30 \mathrm{~mm} \times$ $20 \mathrm{~mm} \times 10 \mathrm{~mm}$ was cut and polished using silicon carbide powder, then stack with glass slide of $26 \mathrm{~mm} \times 42 \mathrm{~mm}$ using a special adherent, then an automated multiplate grinder machine was used to make the slides about $0.030 \mathrm{~mm}$ thinner in thickness, following the procedure laid out by Grundmann and Scholz (74). A Nikon optical microscope was used particularly to identify mineral constituents of the studied basaltic rocks and to determine their mineralogical properties and textures. Modal analysis with five hundred points as recommended by ASTM E562 (75) was used to determine the mineral percentage as $\%$ of volume. The point-counting method depends on using a grid mesh with equally spaced points on the thin section slides, the grid distance, which is the distance between successive points on a grid mesh, should not exceed both grain size and texture. For the same mineral particle, the volume percentage was found by dividing the number of points by the total number of points counted.

\section{RESULTS AND DISCUSSIONS}

\subsection{Petrography analysis}

X-ray Fluorescence Spectrometry (XRF) was used to determine the dominant and minor oxides in rock samples (Table 3). The XRF analysis shows that the majority of oxides are based on plotting the test results on the total alkali $\left(\mathrm{Na}_{2} \mathrm{O}+\mathrm{K}_{2} \mathrm{O}\right)$ versus $\mathrm{SiO}_{2}$ diagram (TAS) as shown in Figures 5a and 5b. The basalt rock in this study is classified as mafic alkaline basalt rock. The basalt samples are considered non-weathered basalt since L.O.I is less than 2.64 wt. \% (76).

XRD test results showed that plagioclase, pyroxene, magnetite, and olivine, are the major minerals in the studied samples (Figure 6).

Based on the microphotographs of mineral components (Figure 7) and modal analysis, plagioclase is the most abundant mineral in the studied rock samples, forming approximately $50 \%$ of the rock volume. Plagioclase was found to be subhedral to euhedral with a tabular shape, with length ranging between $0.5-3.0 \mathrm{~mm}$. Pyroxene, the second most abundant mineral, formed about $20 \%$ of the rock volume. Pyroxene, which is mainly an augite mineral composition, had anhedral to subhedral crystals with a size range between $0.3-1.0 \mathrm{~mm}$ [Figure 7 (c)]. Olivine composed about $13 \%$ of the volume of the rock sample. Olivine crystals range in size between $0.05-0.3 \mathrm{~mm}$. Olivine minerals subjected to hydration and the oxidation process produced brownish iddingsite mineral [Figure 7 (d)]. Magnetite formed about $8 \%$ of the rock volume, the size ranging from $0.03 \mathrm{~mm}$ to $0.5 \mathrm{~m}$ [Figure 7 (a)]. Basalt vascularity (voids) about $6 \%$ by volume, some voids are filled with calcite and chloride minerals [Figure 7 (b)].
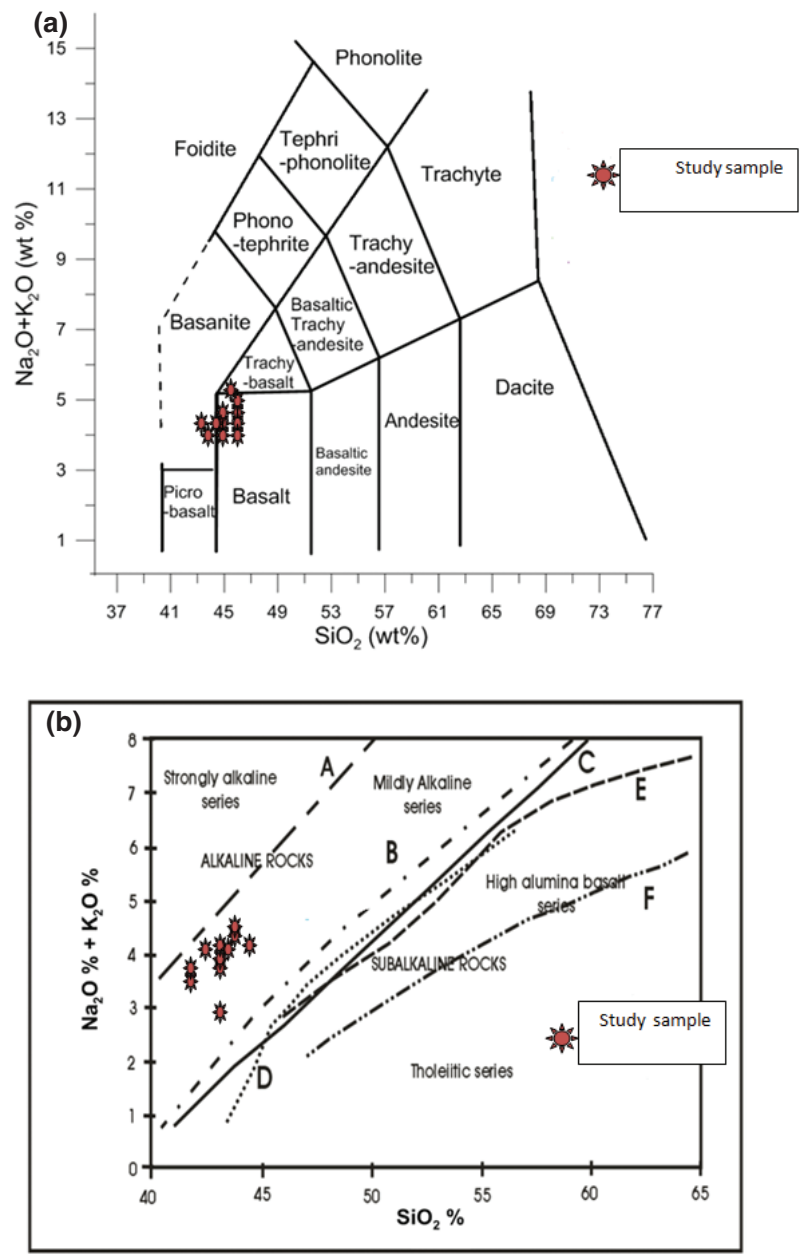

Figure 5. Test results on TAS modified after (77). (b) Test result on total alkaline versus silica diagram modified after (78).

TABLE 3. XRF analysis of studied basalt samples.

\begin{tabular}{lrrrrrrrrrrr}
\hline Mineral & $\mathbf{S i O}_{2}$ & $\mathbf{A l}_{2} \mathbf{O}_{3}$ & $\mathbf{F e}_{2} \mathbf{O}_{3}$ & $\mathbf{C a O}$ & $\mathbf{M g O}$ & $\mathbf{N a}_{\mathbf{2}} \mathbf{O}$ & $\mathbf{T i O}_{2}$ & $\mathbf{K}_{2} \mathbf{O}$ & $\mathbf{P}_{\mathbf{2}} \mathbf{O}_{\mathbf{5}}$ & $\mathbf{M n O}$ & $\mathbf{L} . \mathbf{O . I}$ \\
\hline Mean value, Wt. \% & 45.08 & 14.32 & 12.39 & 11.54 & 8.42 & 3.42 & 1.67 & 0.65 & 0.30 & 0.16 & 2.31 \\
Standard Deviation & 0.56 & 0.55 & 0.34 & 0.69 & 0.38 & 0.29 & 0.05 & 0.07 & 0.05 & 0.01 & 0.40 \\
\hline
\end{tabular}


A secondary mineral-like sericite (weathered plagioclase), iddingsite (weathered olivine), chloride (weathered pyroxene) composed about $3 \%$ by volume. Based on the Modal analysis with 500 points,

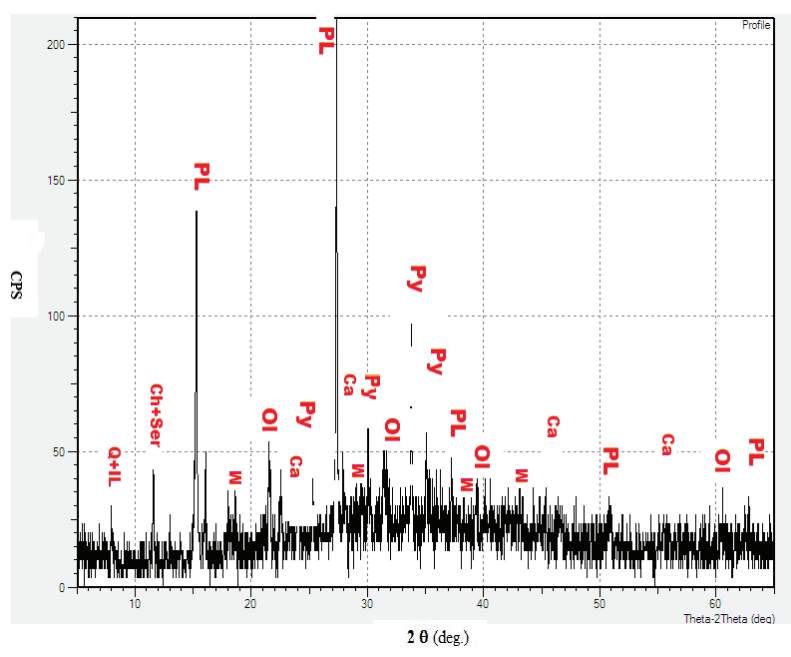

FIGURE 6. XRD analysis of studied basalt samples (PL: plagioclase, Py: pyroxene, OL: olivine, M: magnetite, Ca: calcite, Ch: Chlorite, Ser: Sericite). the rock samples can be classified as plagioclasepyroxene-olivine basalt, according to (79).

\subsection{Mechanical properties}

The results of UCS, $E_{t}$, and LRH tests conducted on 90 core rock specimens extracted from 30 rock boulders collected from the study area are shown in Figure 8. Statistical parameters values of maximum, minimum, mean, coefficient of variation, and standard deviation of the results are shown in Table 4. As seen in Table 4, the mean UCS for the basalt rock samples used in this study was 83.82 $\mathrm{MPa}$, with a range between 51.75 and 115.70 $\mathrm{MPa}$. In addition, the mean of the $\mathrm{E}_{\mathrm{t}}$ about 50.78 $\mathrm{GPa}$, varies between 31.77 and $68.39 \mathrm{GPa}$. This variation of test results might be due to the effect of non-isotropy, mineralogical composition, porosity, and grain boundaries. The current basalt rock was classified as strong to very strong rock based on the UCS results according to ISO 14689-1 (80) classification. On the other hand, the studied basalt rock was designated as medium strength $(\mathrm{CH})$ to high strength (BH) according to Deere and Miller's (81) classification system.
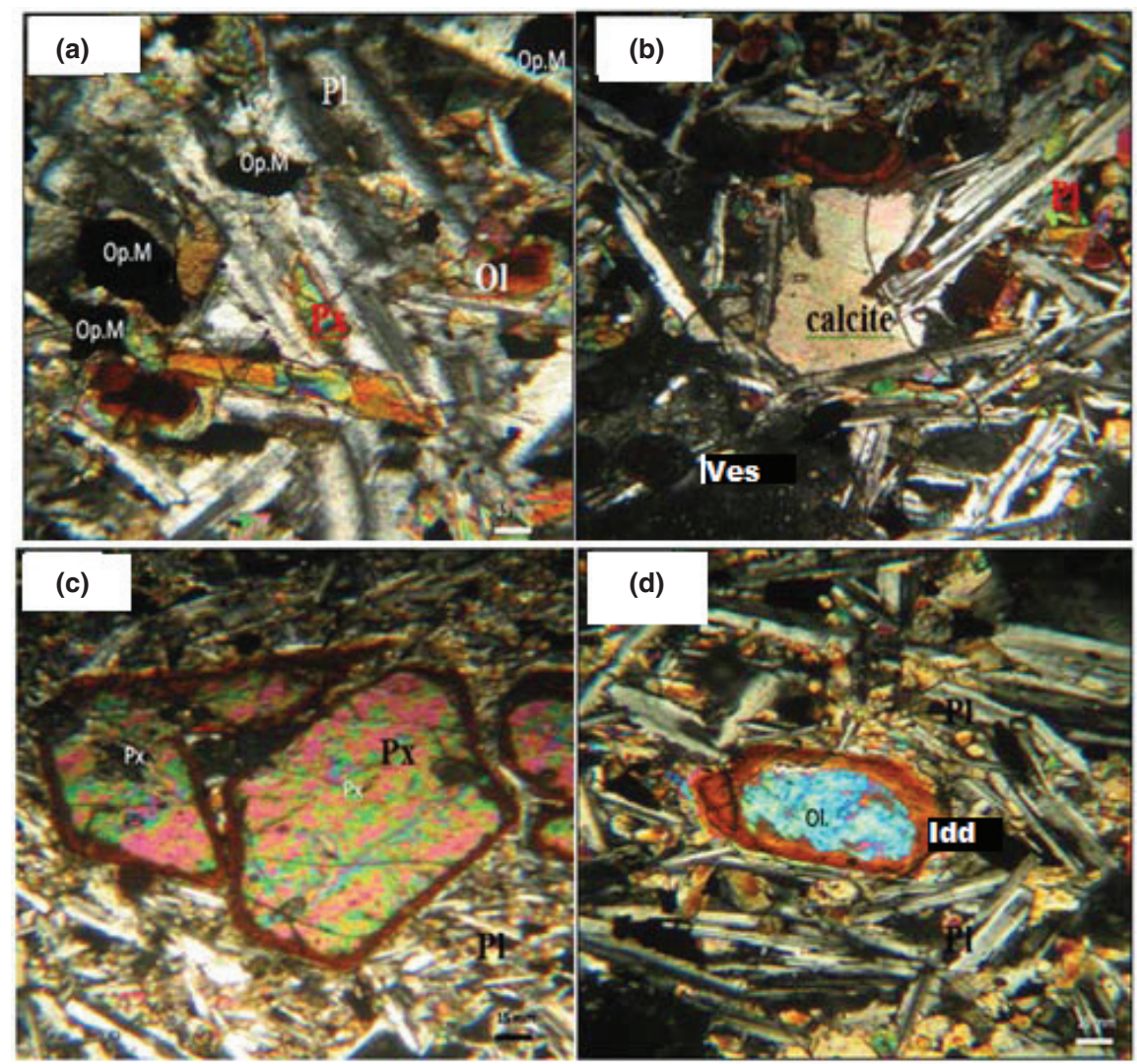

Figure 7. Microphotograph of mineral components, Mag 10x.

(PL: Plagioclase, PX: Pyroxene, OL: Olivine, Idd: Iddingsite, Ca: calcite, Op.M: Magnetite, Ves: vascularity). 

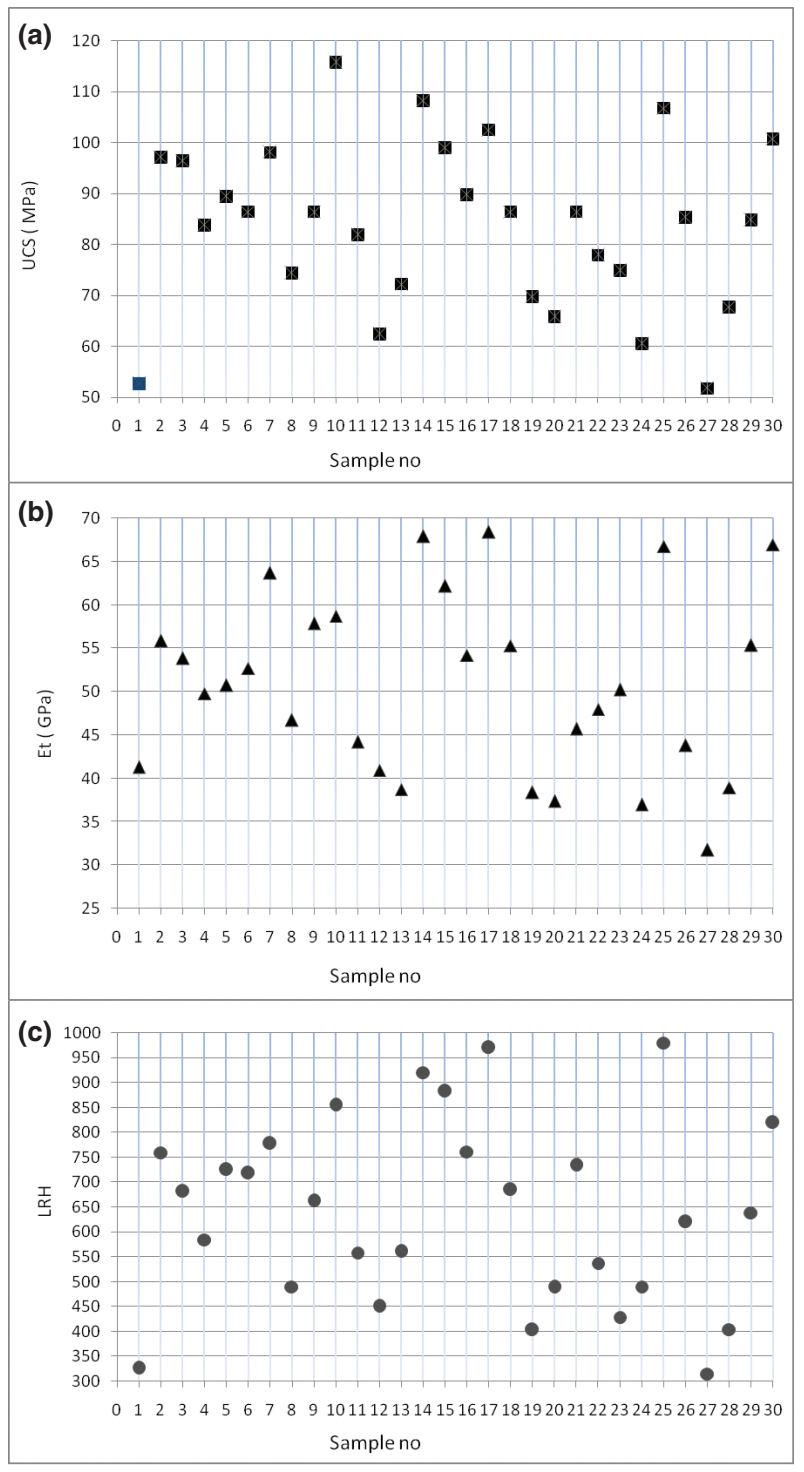

FIGURE 8. Test results distribution. (a) UCS. (b) $\mathrm{E}_{\mathrm{t}}$. (c) LRH (each point is an average of the results of three cores).

Stress-strain curves for the first sample are shown in Figure 9. As illustrated in Figure 9, at initial loading there is a non-linear relationship between stress and strain because, at this stage, there is a closing of preexisting micro-cracks inside the specimen due to the stress history of the rock specimen including rock coring. As the loading increases, the stressstrain curve becomes linear, and the rock behavior is more elastic. After the elastic range, the stressstrain curve becomes nonlinear and large deformation occurs until the maximum stress is reached. The LRH shows an average value of 640.9 with a range between 315 and 980; these values indicate that the basalt rock in the study area has a high hardness. The high hardness can be explained by the fact that the basalt rock is composed of plagioclase, pyroxene,
TABLE 4. Statistical parameters of tested samples.

\begin{tabular}{lccc}
\hline & USC $(\mathbf{M P a})$ & $\mathbf{E}_{\mathbf{t}}(\mathbf{G P a})$ & $\mathbf{L R H}$ \\
\hline Mean & 83.82 & 50.78 & 640.9 \\
Max & 115.70 & 68.39 & 980.0 \\
Min & 51.75 & 31.77 & 315.0 \\
$\mathrm{SD}$ & 16.4 & 10.4 & 186.3 \\
$\mathrm{CV}(\%)$ & $19.5 \%$ & $20.4 \%$ & $29.06 \%$ \\
$\mathrm{~N}^{*}$ & 30 & 30 & 30 \\
\hline
\end{tabular}

* note: $\mathrm{N}$ is an average of the results of three cores

and olivine minerals that have a hardness on Mohs' scale of $6,6.6$, and 6.5 , respectively. The variation is due to micro-crack and small voids.

\subsection{Regression analysis}

The prediction of UCS and $\mathrm{E}_{\mathrm{t}}$ using simple regression from non-destructive simple tests are widely used by many researchers (82-84). In this research, simple regression equations such as linear, exponential, logarithm, and power were adapted to examine the relationship between UCS, $E_{t}$, and LRH test values of basalt rock. Both UCS and $\mathrm{E}_{\mathrm{t}}$ increased with the increase LRH value (Figure 10 and 11).

Moreover, to evaluate the predicted simple regression equations (linear, power, logarithm, and polynomial) and to select the best equation to estimate both UCS and $E_{t}$ based on LRH value, the evaluation was conducted based on statistical performance indices, coefficient of determination $\left(\mathrm{R}^{2}\right)$, and root mean square error (RMSE), which has been adapted by many researchers $(85,86)$. A strong correlation model can be considered if $\mathrm{R}^{2}$ equals 1.0 and RMSE are close to zero $(29,33)$. The equations of these indices are listed below as Equations [2] and [3], and the results for each regression model are presented in Table 5. The power equation is the best equation to predict UCS, while the linear is best to predict $\mathrm{E}_{\mathrm{t}}$.

$$
\begin{aligned}
& R^{2}=1-\left(\frac{\sum_{\mathrm{i}=1}^{\mathrm{n}}(\mathrm{ym}-\mathrm{yp})^{2}}{\sum_{\mathrm{i}=1}^{\mathrm{n}}(\mathrm{ym}-\mathrm{ya})^{2}}\right) \\
& \mathrm{RMSE}=\sqrt{\frac{1}{\mathrm{n}} \sum_{\mathrm{i}=1}^{\mathrm{n}}(\mathrm{ym}-\mathrm{yp})^{2}}
\end{aligned}
$$

Where ym: measured value, yp: predicted value, ya: an average of the measured value, $n$ : total number of data.

To check the validity of these correlations, UCS and $E_{t}$ calculated from the adapted correlations were presented with the measured values (Figures 12 and 13). It can be concluded that these correlations 
$10 \bullet$ H. Aldeeky et al.

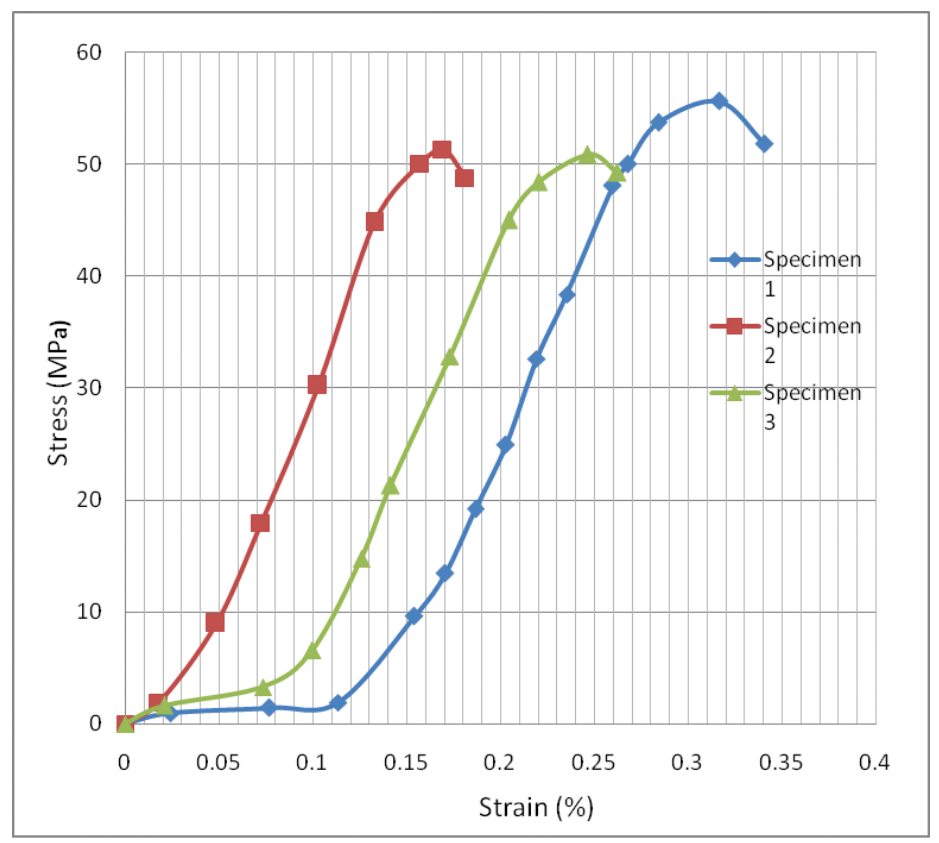

FiguRE 9. Stress-strain curves for the first sample.

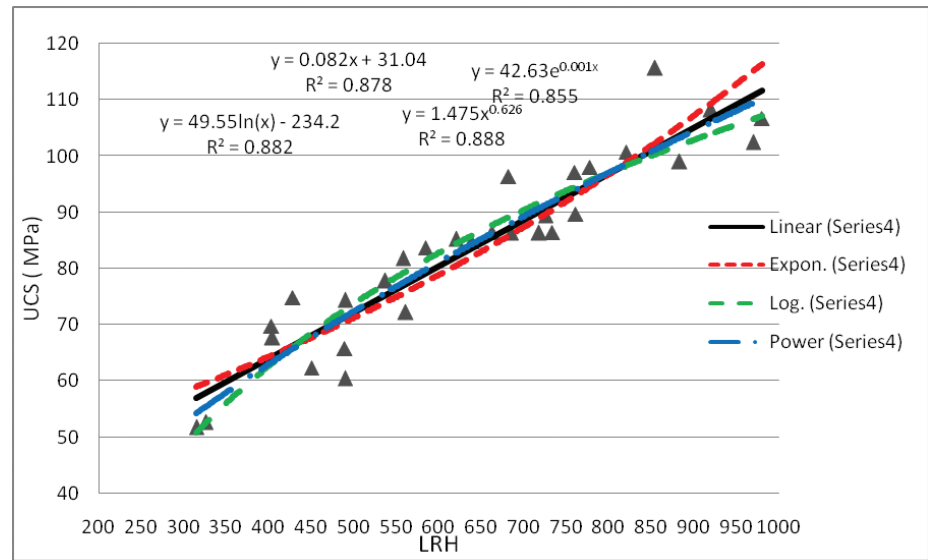

FIGURE 10. Correlation between USC and LRH

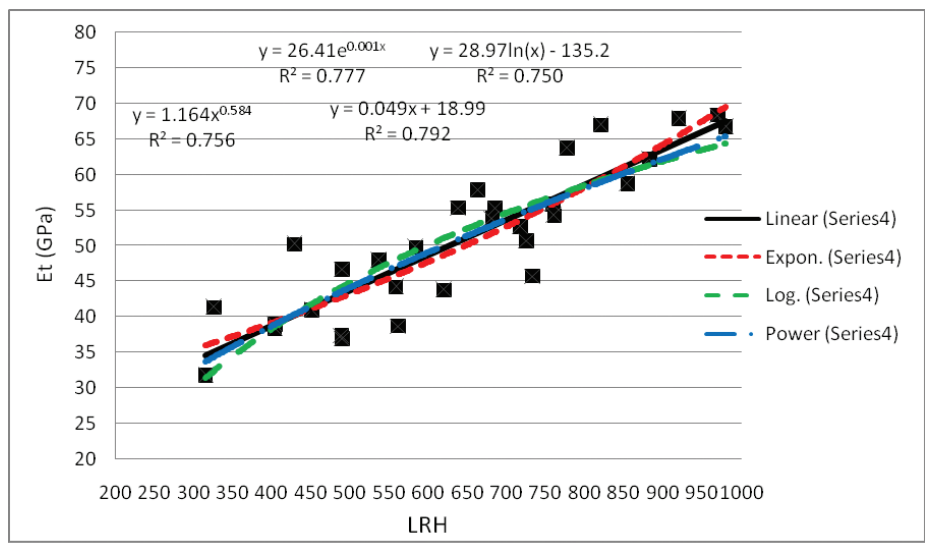

FIGURE 11. Correlation between $\mathrm{E}_{\mathrm{t}}$ and LRH. 
Assessing the uniaxial compressive strength and tangent Young's modulus of basalt rock using the Leeb rebound hardness test $\bullet 11$

TABLE 5. Results of statistical regression models for UCS, $E_{t}$ predictions.

\begin{tabular}{lllcc}
\hline Mechanical properties & Regression type & \multicolumn{1}{c}{ Equation No. } & $\mathbf{R}^{\mathbf{2}}$ & RMSE \\
\hline \multirow{3}{*}{$\mathrm{UCS}$} & Linear & $\mathrm{UCS}=0.082(\mathrm{LRH})+31.049$ & 0.878 & 5.621 \\
& Exponential & $\mathrm{UCS}=42.633 \mathrm{EXP}(0.001 \mathrm{LRH})$ & 0.855 & 6.368 \\
& Logarithmic & $\mathrm{UCS}=49.553 \mathrm{Ln}(\mathrm{LRH})-234.24$ & 0.882 & 5.512 \\
& power & $\mathrm{UCS}=1.475(\mathrm{LRH}))^{0.6264}$ & 0.888 & 5.464 \\
$\mathrm{Et}$ & Linear & $\mathrm{E}_{\mathrm{t}}=0.0496(\mathrm{LRH})+18.993$ & 0.792 & 4.661 \\
& Exponential & $\mathrm{E}_{\mathrm{t}}=26.41 \mathrm{EXP}(0.001 \mathrm{LRH})$ & 0.777 & 4.603 \\
& Logarithmic & $\mathrm{E}_{\mathrm{t}}=28.976 \mathrm{Ln}(\mathrm{LRH})-135.21$ & 0.750 & 5.091 \\
& power & $\mathrm{E}_{\mathrm{t}}=1.1645(\mathrm{LRH})$ & 0.5849 & 4.856 \\
\hline
\end{tabular}

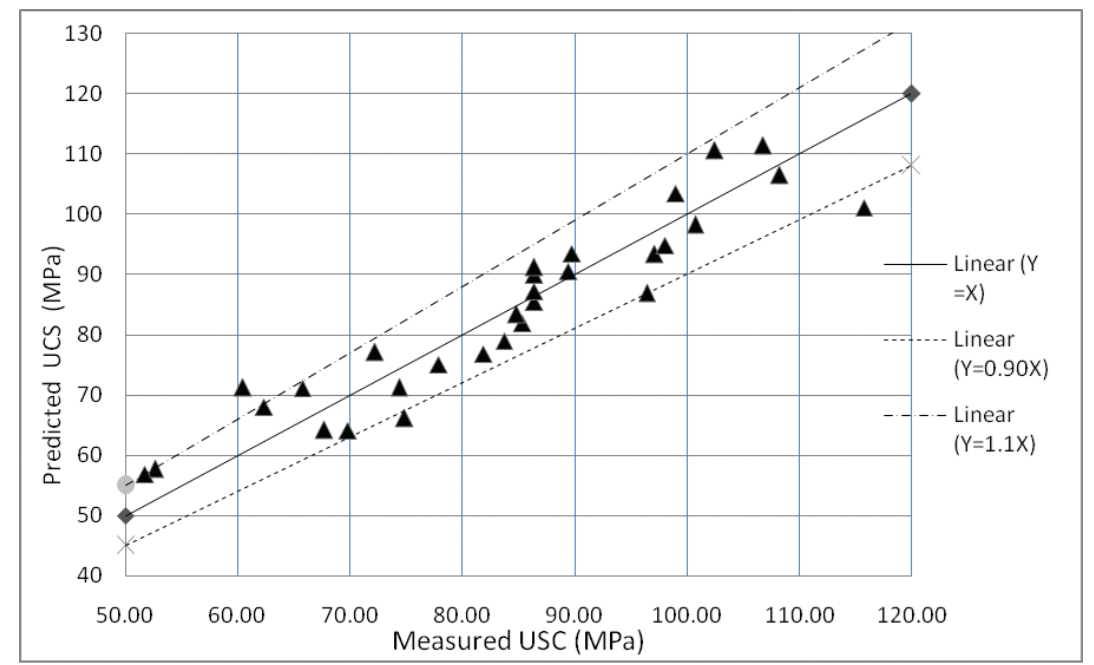

FIGURE 12. Mapped experimental results and predicted UCS.

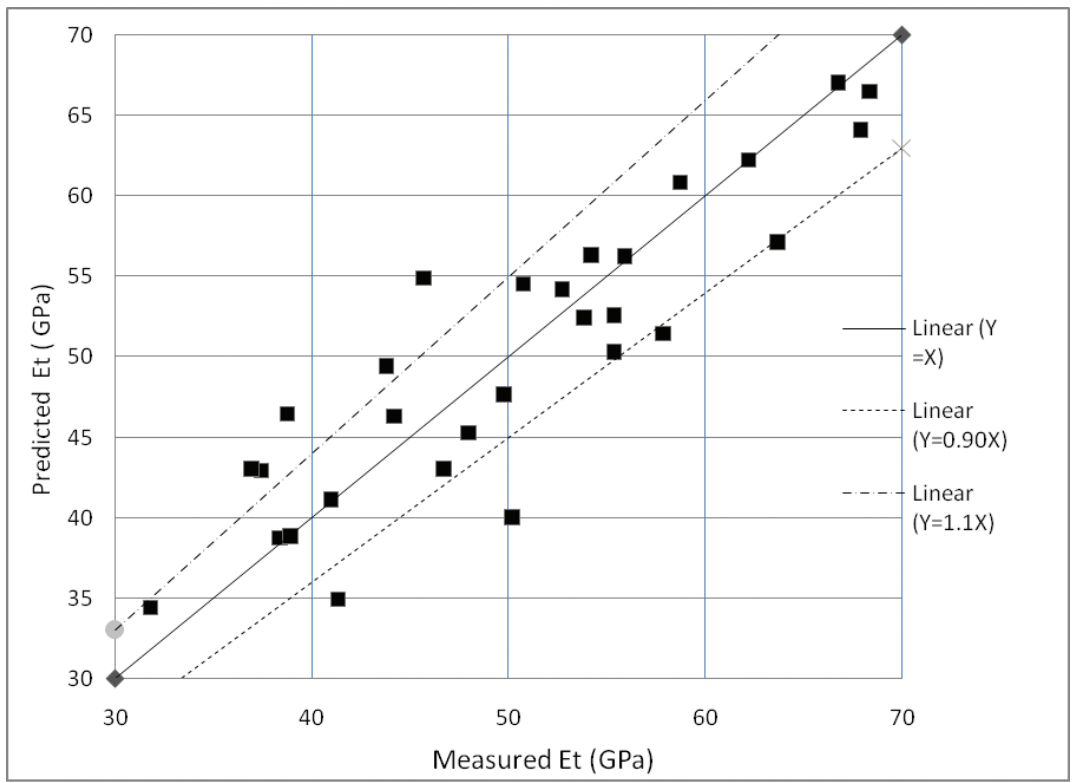

FIGURE 13. Mapped experimental results and predicted $\mathrm{E}_{\mathrm{t}}$. 
are highly reliable in estimating both the UCS and the $\mathrm{E}_{\mathrm{t}}$ since the majority scattered around the quality line $(y=x)$ lay within the range $\pm 20 \%$.

On the other hand, to check the validity of the power correlation proposed in this study to predict USC value for different rock types, the predicted values compared with measured values collected from previous literature (Figure 14). It can be concluded that for very low to low strength (class E and D) the predicted values are overestimated by the proposed correlations; for medium-strength (class C), the predicted value lays within $\pm 20 \%$ of the measured values; while for high and very high strength (class $\mathrm{A}$ and $\mathrm{B}$ ) the predicted values are underestimated.

However, the proposed power correlation to predict UCS in this study was compared with other researchers' correlations presented in Table 1. The majority of the previous relationship is power relations which agree with this study. However, the previous studies included different rock types with a wide range of strength varied between very weak to very strong rock, while in the current study the rock samples were collected from the same source with little variation in UCS (Figure 15).

\section{CONCLUSIONS}

This research examined the correlation between LRH and the mechanical engineering properties for both UCS and $E_{t}$ for basalt rock. In this investigation, LRH value, UCS and $\mathrm{E}_{\mathrm{t}}$ were conducted on core specimens extracted from 30 different boulders collected from the neighboring area of Umm al-Jimal city. Linear regression was performed to correlate LRH value with both the UCS and the $\mathrm{E}_{t}$ of basalt rock. From the analysis conducted, the following conclusions can be drawn:

1. A strong to moderate strong correlation of power regression was found between Lee rebound hardness value $(\mathrm{LRH})$ and UCS with $\left(\mathrm{R}^{2}=0.888\right.$, RMSE $=5.464$ ) and moderate strong linear with the $\mathrm{E}_{\mathrm{t}}$ with $\left(\mathrm{R}^{2}=0.888, \mathrm{RMSE}=5.464\right)$. The results indicate that with the increase in LRH

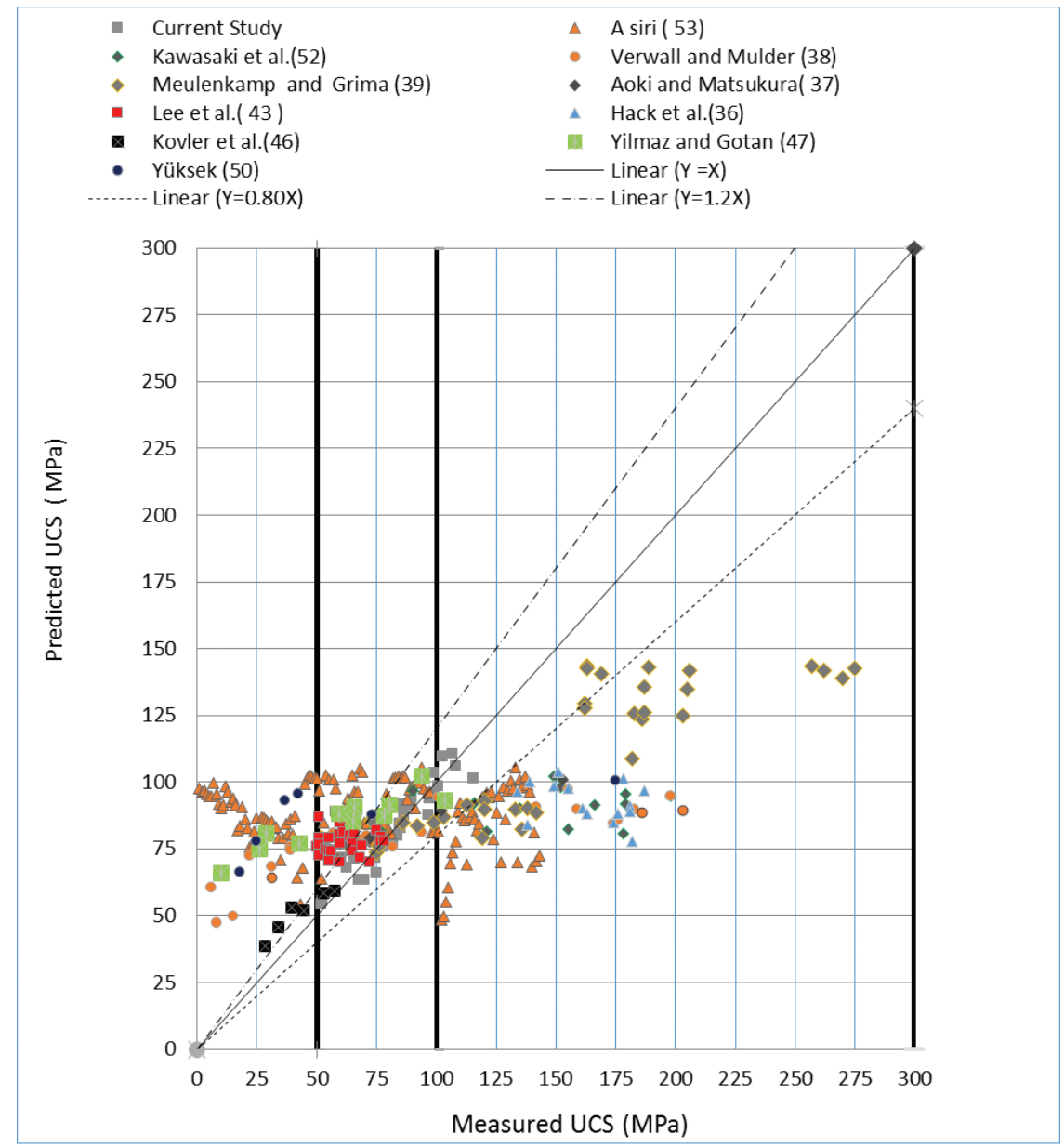

FIGURE 14. Experimental and predicted UCS results using proposed linear correlation. 


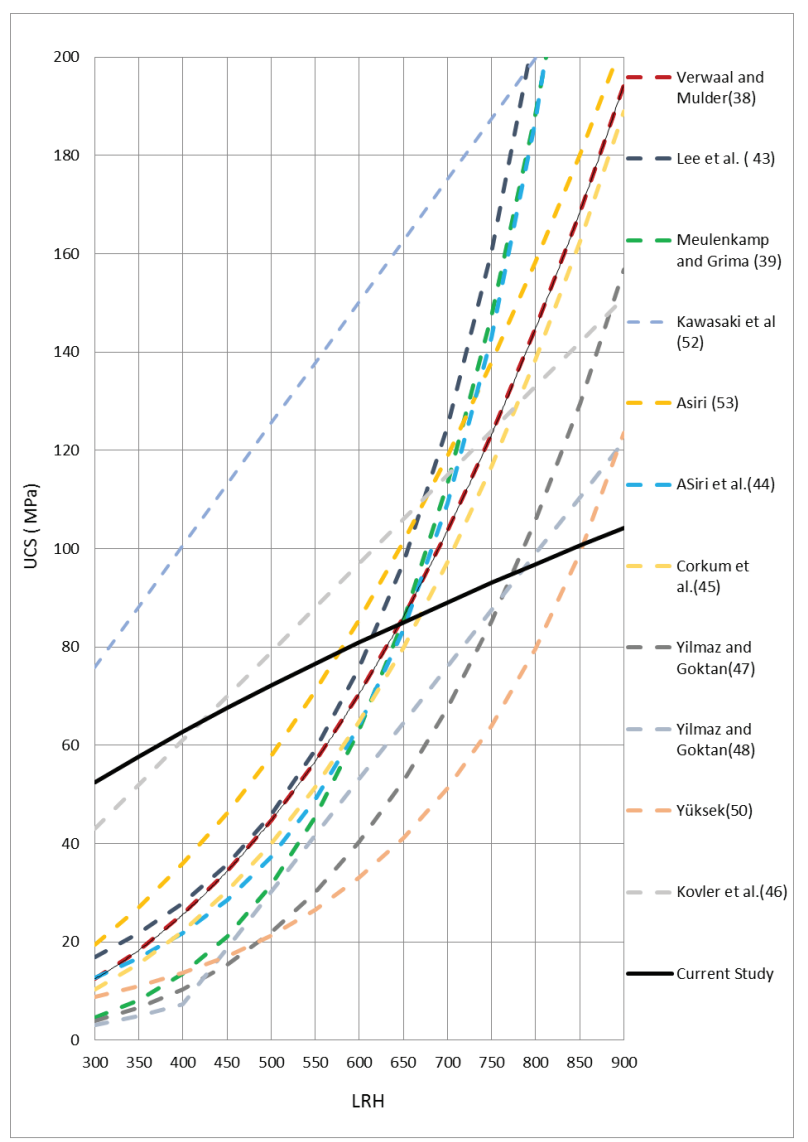

FIGURE 15. Comparison with some previous correlations to predict UCS from LRH.

value, the value of both the UCS and the $\mathrm{E}_{\mathrm{t}}$ increases.

2. UCS and $\mathrm{E}_{\mathrm{t}}$ of basalt rock already utilized as a building stone in historic buildings can be estimated using simple, portable, non-destructive LRH tests rather than obtaining destructive core samples.

3. These proposed correlations are limited and only applicable for strong to very strong basalt rock with low porosity in the study area.

\section{ACKNOWLEDGEMENT}

The authors would like to thank Mr. Tareq Albeshety from the geology department at Al Hashemite University for his help in conducting XRD and thin section. Our great thanks to Prof. Ahmad alMalabeh from the geology department at Al Hashemite University for reviewing and revising the petrography analysis part; his help is really appreciated.

\section{REFERENCES}

1. Singh, R.; Umrao, R.K.; Singh, T.N. (2014) Stability evaluation of road-cut slopes in the Lesser Himalaya of Uttarakhand, India: conventional and numerical approaches. Bull. Eng. Geol. Environ. 73, 845-857. https:// doi.org/10.1007/s10064-013-0532-1.

2. Sivakugan, N.; Das, B.M.; Lovisa, J.; Patra, C.R. (2014) Determination of $\mathrm{c}$ and $\varphi$ of rocks from indirect tensile strength and uniaxial compressive tests. Int. J. Geot. Eng. 8 [1], 59-65. https://doi.org/10.1179/1938636213Z.00000000053.

3. Endait, M.; Juneja, A. (2015) New correlations between uniaxial compressive strength and point load strength of basalt. Int. J. Geot. Eng. 9 [4], 348-353. https://doi.org/10.1179/1939 787914Y.0000000073.

4. Umrao, R.K.; Singh, R.; Singh, T.N. (2015) Stability evaluation of hill cut slopes along national highway-13 near Hospet, Karnataka, India. Georisk. 9 [3], 158-170. https:// doi.org/10.1080/17499518.2015.1053494.

5. Armaghani, D.J.; Mohamad, E.T.; Momeni, E.; Monjezi, M.; Narayanasamy, M.S. (2016) Prediction of the strength and elasticity modulus of granite through an expert artificial neural network. Arab. J. Geosocial. 9, 48. https://doi. org/10.1007/s12517-015-2057-3.

6. Sharma, L.K.; Singh, R.; Umrao, R.K.; Sharma, K.M.; Singh, T.N. (2017) Evaluating the modulus of elasticity of soil using soft computing system. Eng. Comp. 33, 497-507. https://doi.org/10.1007/s00366-016-0486-6.

7. ISRM (2007) The complete ISRM suggested methods for rock characterization, testing and monitoring in: Ulusay, R., Hudson, J.A. (eds). Suggested methods prepared by the commission on testing methods. International Society for Rock Mechanics, ISRM Turkish National Group, Ankara, p 628.

8. ASTM D7012 (2014) Standard Test Methods for Compressive Strength and Elastic Moduli of Intact Rock Core Specimens under Varying States of Stress and Temperatures, ASTM International, West Conshohocken, PA. https://doi.org/10.1520/D7012-14E01.

9. Beiki, M.; Majdim, A.; Givshad, A.D. (2013) Application of genetic programming to predict the uniaxial compressive strength and elastic modulus of carbonate rocks. Int. J. Rock Mech. Mining Sci. 63, 159-169. https://doi. org/10.1016/j.ijrmms.2013.08.004.

10. Karakuş, A.; Akatay, M. (2013) Determination of basic physical and mechanical properties of basaltic rocks from P-wave velocity. Nondestrcut. Test. Eval. 28, 342-353. https://doi.org/10.1080/10589759.2013.823606.

11. Azadan, P.; Ahangari, K. (2014) Evaluation of the new dynamic needle penetrometer in estimating uniaxial compressive strength of weak rocks. Arab. J. Geosocial 7, 3205-3216. https://doi.org/10.1007/s12517-013-0921-6.

12. Fakir, M.; Ferentinou, M.; Misra, S. (2017) An investigation into the rock properties influencing the strength in some granitoid rocks of KwaZulu-Natal, South Africa. Geotech. Geol. Eng. 35, 1119-1140. https://doi. org/10.1007/s10706-017-0168-1.

13. Heidari, M.; Khanlari, G.R.; Kaveh, M.T.; Kargarian, S. (2012) Predicting the uniaxial compressive and tensile strengths of gypsum rock by point load testing. Rock. Mech. Rock. Eng. 45, 265-273. https://doi.org/10.1007/ s00603-011-0196-8.

14. Umrao, R.K.; Sharma, L.K.; Singh, R : Singh, T.N. (2018) Determination of strength and modulus of elasticity of heterogenous sedimentary rocks: An ANFIS predictive technique. Measur. 126, 194-201. https://doi.org/10.1016/j. measurement 2018.05.064

15. Yilmaz, I.; Yuksek, G. (2009) Prediction of the strength and elasticity modulus of gypsum using multiple regression, ANN, and ANFIS models. Int J Rock Mech. Mining Sci. 46, 803-810. https://doi.org/10.1016/j.ijrmms.2008.09.002.

16. Yagi, S. (2011) P-wave velocity test for assessment of geotechnical properties of some rock materials. Bull. Mater. Sci. 34, 947-953.

17. Monjezi, M.; Khoshalan, H.A.; Razifard, M. (2012) A neuro-genetic network for predicting uniaxial compressive strength of rocks. Geotech. Geol. Eng. 30, 1053-1063. https://doi.org/10.1007/s10706-012-9510-9.

18. Yasar, E.; Erdogan, Y. (2004) Estimation of rock physic mechanical properties using hardness methods. J. Eng. Geo. 71, 281-288. https://doi.org/10.1016/S0013-7952(03) 00141-8. 
19. Yurdakul, M.; Ceylan, H.; Akdas, H. (2011) A predictive model for uniaxial compressive strength of carbonate rocks from Schmidt hardness, in: Civil, Constr. Envir. Eng. Conf. Pres. and Proc. paper 7.1

20. Singh, T.N.; Kainthola, A.; Venkatesh, A. (2012) Correlation between point load index and uniaxial compressive strength for different rock types. Rock. Mech. Rock. Eng. 45, 259-264. https://doi.org/10.1007/s00603-011-0192-z.

21. Singh, R.; Vishal, V.; Singh, T.N.; Ranjith, P.G. (2012) A comparative study of generalized regression neural network approach and adaptive neuro-fuzzy inference systems for prediction of unconfined compressive strength of rocks. Neural. Comput. Appl. 23, 499-506. https://doi.org/10.1007/ s00521-012-0944-z.

22. Anikoh, G.A.; Adesida, P.A.; Afolabi, O.C. (2015) Investigation of physical and mechanical properties of selected rock types in kogi state using hardness tests. J. Min. Wor. Exp. (MWE). 4, 37-51.

23. Lai, G.T.; Rafek, A.G.; Serasa, A.S.; Hussin, A.; Ern, L.K. (2016) Use of ultrasonic velocity travel time to estimate uniaxial compressive strength of granite and schist in Malaysia . Sains Malaysiana. 45 [2], 185-1939.

24. Singh, R.; Umrao, R.K.; Ahmad, M.; Ansari, M.K.; Sharma, L.K.; Singh, T.N. (2017) Prediction of geo mechanical parameters using soft computing and multiple regression approach. Measurt. 99, 108-119. https://doi. org/10.1016/j.measurement.2016.12.023.

25. Karaman, K.; Kesimal, A. (2015) A comparative study of Schmidt hammer test methods for estimating the uniaxial compressive strength of rocks. Bull. Eng. Geol. Environ. 74 , 507-520. https://doi.org/10.1007/s10064-014-0617-5.

26. Fereidooni, D. (2016) Determination of the geotechnical characteristics of Hornfelsic rocks with a particular emphasis on the correlation between physical and mechanical properties. Rock. Mech. Rock. Eng. 49, 2595-2608. https://doi.org/10.1007/s00603-016-0930-3.

27. Wang, H.; Lin, H.; Cao, P. (2017) Correlation of UCS rating with Schmidt hammer surface hardness for rock mass classification. Rock. Mech. Rock. Eng. 50, 195-203. https:// doi.org/10.1007/s00603-016-1044-7.

28. Lai, G.T.; Mazlan, N.A.; Nadzir, M.S.M.; Rafek, A.G.; Serasa, A.S.; Hussin, A.; Ern, L.K.; Yeok, F.S. (2017) Uniaxial compressive strength of Antarctic Peninsula rocks: Schmidt hammer rebound test .Sains Malaysiana. 46 [5], 677-684.

29. Rajabi, A.M.; Hosseini, A.; Alireza Heidari, A. (2017) The new empirical formula to estimate the uniaxial compressive strength of limestone; north of saveh a case study. J. Eng. Geo. 11 [3], 159-180.

30. Daoud, H.S.; Younis, M.; Alshkane; Rashed, K.A. (2018) Prediction of uniaxial compressive strength and modulus of elasticity for some sedimentary rocks in Kurdistan Region- Iraq using Schmidt hammer. Kirkuk Uni. J. Sci. Stu. (KUJSS). 13 [1], 52-67.

31. El-Sayed, S.A.S.; Abdulelah, A.B.; Abd El-Hamed, A.E-H. (2018) Geotechnical properties of Precambrian carbonate, Saudi Arabia. Arab. J. Geosocial. 11, 500. https://doi. org/10.1007/s12517-018-3821-y.

32. Fereidooni, D.; Khajevand, R. (2018) Determining the geotechnical characteristics of some sedimentary rocks from Iran with an emphasis on the correlations between physical, index and mechanical properties. Geotech. Test. J. 41 [3], 555-573. https://doi.org/10.1520/GTJ20170058.

33. Heidari, M.; Mohseni, H.; Jalali, S.H. (2018) Prediction of uniaxial compressive strength of some sedimentary rocks by fuzzy and regression models. Geotech. Geol. Eng. 36, 401-412. https://doi.org/10.1007/s10706-017-0334-5.

34. Kong, F.; Shang, J. (2018) A validation study for the estimation of uniaxial compressive strength based on index tests. Rock. Mech. Rock. Eng. 51, 2289-2297. https://doi. org/10.1007/s00603-018-1462-9.

35. Sari, M. (2018) Investigating relationships between engineering properties of various rock types. Glob. J. Earth. Sci. Eng. 5, 1-25. https://doi.org/10.15377/2409-5710.2018.05.1.

36. Hack, H.; Hingira, J.; Verwaal, W. (1933) Determination of discontinuity wall strength by Equotip and ball rebound tests.
Int. J. Rock. Mech. Mining. Sci. Geo. Mechan. Abstr. 30 [2], 151-155. https://doi.org/10.1016/0148-9062(93)90707-K

37. Aoki, H.; Matsukura, Y. (2008) Estimating the unconfined compressive strength of intact rocks from Equotip hardness. Bull. Eng. Geol. Environ. 67, 23-29. https://doi. org/10.1007/s10064-007-0116-z.

38. Verwaal, W.; Mulder, A. (1993) Estimating rock strength with the Equotip hardness tester. Int. J. Rock. Mech. Mining. Sci. Geo. Mechan. Abstr. 30 [6], 659-662. https:// doi.org/10.1016/0148-9062(93)91226-9.

39. Meulenkamp, F.; Álvarez Grima, M. (1999) Application of neural networks for the prediction of the unconfined compressive strength (UCS) from Equotip hardness. Int. J. Rock Mech. Mining. Sci. 36 [1], 29-39. https://doi.org/10.1016/ S0148-9062(98)00173-9.

40. Okawa, S.; Ohoka, M.; Funato, A. (1999) Application of hardness tester to rock specimens. In: Proceedings of the 29 th symposium of rock mechanics. 256-260.

41. Kawasaki, S.; Yoshida, M.; Tanimoto, C.; Masuya, T. (2000) The development of property evaluation method for rock materials based on the simple rebound hardness test: investigations on the effects of test conditions and fundamental properties. J. Japan. Soci. Eng. Geol. 41 [4], 230-241. https://doi.org/10.5110/jjseg.41.230.

42. Yilmaz, N.G. (2013) The influence of testing procedures on uniaxial compressive strength prediction of carbonate rocks from Equotip hardness tester (EHT) and proposal of a new testing methodology: hybrid dynamic hardness (HDH). Rock. Mech. Rock. Eng. 46, 95-106. https://doi. org/10.1007/s00603-012-0261-y.

43. Lee, J.S.; Smallwood, L.; Morgan, E. (2014) New Application of Rebound Hardness Numbers to Generate Logging of Unconfined Compressive Strength in Laminated Shale Formations. In: $48^{\text {th }}$ US Rock Mechanics/Geo mechanics Symposium. American Rock Mechanics Association.

44. Asiri, Y.; Corkum, A.; El Naggar, H. (2016) Leeb hardness test for UCS estimation of sandstone. $69^{\text {th }}$ Geo Vancouver Conference, Vancouver, October.

45. Corkum, A.G.; Asiri, Y.; El Naggar, H.; Kinakin, D. (2018) The Leeb hardness test for rock: an updated methodology and UCS correlation. Rock. Mech. Rock. Eng. 51, 665-675. https://doi.org/10.1007/s00603-017-1372-2.

46. Kovler, K.; Wang, F; Muravin, B. (2018) Testing of concrete by rebound method: Leeb versus Schmidt hammers. Mater. Struct. 51, 138. https://doi.org/10.1617/s11527-018-1265-1.

47. Gunez Yilmaz, N.; Goktan, R.M. (2019) Comparison and combination of two NDT methods with implications for compressive strength evaluation of selected masonry and building stones. Bull. Eng. Geol. Environ. 78, 4493-4503. https://doi.org/10.1007/s10064-018-1382-7.

48. Yilmaz, N.G.; Göktan, R.M. (2018) Analysis of the Leeb hardness test data obtained by using two different rock core holders. SDU. J. Nat. App. SC.

49. Celik, S.B.; Çobanoğlu, I. (2019) Comparative investigation of Shore, Schmidt, and Leeb hardness tests in the characterization of rock materials. Environ. Earth. Sci. 78, 554. https://doi.org/10.1007/s12665-019-8567-7.

50. Yüksek, S. (2019) Mechanical properties of some building stones from volcanic deposits of mount Erciyes (Turkey). Mater. Construcc. 69 [334], e187. https://doi.org/10.3989/ mc.2019.04618.

51. Desarnaud, J.; Kiriyama, K.; Simsir, B.B.; Wilhelm, K.; Viles, H. (2019) A laboratory study of Equotip surface hardness measurements on a range of sandstones: What influences the values and what do they mean? Earth Surf. Process. Landforms. 44 [7], 1419-1429. https://doi. org/10.1002/esp.4584.

52. Kawasaki, S.; Tanimoto, C.; Koizumi, K.; Ishikawa, M (2002) An attempt to estimate mechanical properties of rocks using the Equotip Hard ness tester Jo. Japan. Soci. Eng. Geol. 43, 244-248. https://doi.org/10.5110/ jjseg.43.244

53. Asiti, Y.; Corkum, A.; El Naggar, H. (2017) Standardized process for field estimation of unconfined compressive strength using Leeb hardness. MASc, Dalhousie University, Halifax. (2017). 
54. El-Hasan, T; Al-Malabeh, A. (2008) Geochemistry, mineralogy and petrogenesis of El-Lajjoun Pleistocene alkali basalt of central Jordan. Jordan. J. Earth. Envir. Sci. 1, $53-62$.

55. Bany Yaseen, I.A.A.; Abidrabbu, A.Y. (2016) Mineralogy, petrology and geochemistry of the basalt flows at Ash-Shuna Ash-Shamaliyya area, north west Jordan. Earth. Sci. 5 [6], 82-95.

56. Al Kuisi, M.; Abed, A.M.; Mashal, K.; Saffarini, G.; Saqhour, F. (2015) Hydrogeochemistry of groundwater from karstic limestone aquifer highlighting arsenic contamination: case study from Jordan. Arab. J. Geosci. 8, 9699-9720. https://doi.org/10.1007/s12517-015-1919-z.

57. Abu-Mahfouz, I.S.; Al-Malabeh, A.A.; Rababeh, S.M. (2016) Geo-engineering evaluation of Harrat Irbid Basaltic Rocks, Irbid District-North Jordan. Arab. J. Geosci. 9, 412. https://doi.org/10.1007/s12517-016-2428-4

58. Smadi, A.K. (2016) Mineralogy, geochemistry and petrogensis of selected basaltic outcrops in central parts of Irbid Governorate, North Jordan. Master of Science in Geology Thesis, Yarmouk University, Irbid Jordan. 137.

59. Al-Share, R.; Momami, W.; Obeidat, A.; Mansour, N. (2012) Natural stone in Jordan: characteristics and specifications and its importance in interior architecture. Amer. $J$. Scien. Res. 82, 83-94.

60. Al-Baijat, H. (2008) The use of basalt aggregates in concrete mixes in Jordan. Jordan. J. Civ. Eng. 2 [1], 63-70.

61. Ibrahim A.; Faisal, S.; Jamil, N. (2009) Use of basalt in asphalt concrete mixes. Constr. Build. Mater. 23 [1], 498-506. https://doi.org/10.1016/j.conbuildmat.2007.10.026.

62. Tarawaneh, K.; El-Hamed, S.; Abdel Hadi, N.; Rabba, I. (2001) Evaluation of the geological and engineering properties of basalt of northeast Jordan for construction uses (Case Study) Jordan Engineering Association, Amman, Jordan.

63. Leeb, D. (1979) Dynamic hardness testing of metallic materials. NDT. Int. 12 [6], 274-278, https://doi.org/10. 1016/0308-9126(79)90087-7.

64. Viles, H.; Goudie, A.; Grab, S.; Lalley, J. (2011) The use of the Schmidt hammer and Equotip for rock hardness assessment in geomorphology and heritage science: a comparative analysis. Earth. Sur. Proc. Land. 36 [3], 320-333. https://doi. org/10.1002/esp. 2040

65. Aoki, H.; Matsukura, Y. (2007) A new technique for nondestructive field measurement of rock-surface strength: an application of the Equotip hardness tester to weathering studies. Earth. Sur. Proc. Land. 32 [12], 1759-1769. https://doi.org/10.1002/esp.1492.

66. ASTM D4543. (2008) Standard Practices for Preparing Rock Core as Cylindrical Test Specimens and Verifying Conformance to Dimensional and Shape Tolerances, ASTM International, West Conshohocken, PA. https://doi. org/10.1520/D4543-08.

67. ASTM A 966. (2012) Standard Test Method for Leeb Hardness Testing of Steel Products, ASTM International, West Conshohocken, PA. https://doi.org/10.1520/A0956-12.

68. Daniels, G.; Mcphee, C.; Sorrentino, Y; McCurdy, P. (2012) Non-destructive strength index testing applications for sand failure evaluation. Proceedings of SPE Asia Pacific Oil and Gas Conference and Exhibition, (L), 1-12.

69. ASTM D7012-10. (2010) Standard Test Method for Compressive Strength and Elastic Moduli of Intact Rock Core Specimens under Varying States of Stress and Temperatures. ASTM International, West Conshohocken, PA. https://doi.org/10.1520/D7012-10.

70. Bejarbaneh, B.Y.; Bejarbaneh, E.Y.; Amin, M.F.M.; Fahimifar, A.; Armaghani, D.J.; Majid, M.Z.A. (2018) Intelligent modelling of sandstone deformation behavior using fuzzy logic and neural network systems. Bull.
Eng. Geol. Environ. 77, 345-361. https://doi.org/10.1007/ s10064-016-0983-2.

71. Małkowski, P.; Ostrowski, L.; Brodny, J. (2018) Analysis of Young's modulus for Carboniferous sedimentary rocks and its relationship with uniaxial compressive strength using different methods of modulus determination. $J$. Sust. Mining. 17 [3], 145-157. https://doi.org/10.1016/j.jsm. 2018.07.002.

72. ASTM E1621-13. (2013). Standard Guide for Elemental Analysis by Wavelength Dispersive X-Ray Fluorescence Spectrometry, ASTM International, West Conshohocken, PA. https://doi.org/10.1520/e1621-94r99.

73. Poppe, L.J.; Paskevich, V.F.; Hathaway, J.C.; Blackwood, D.S. (2000) A laboratory manual for X-ray powder doffraction. https://doi.org/10.3133/ofr0141.

74. Grundmann, G.; Scholz, H. (2015). Preparation methods in mineralogy \& geology: the preparation of thin sections, polished sections, acetate foil prints, preparation for elutriation analysis, and staining tests for the optical and electron microscopy. (2015) https://doi.org/10.13140/ RG.2.1.2593.9360.

75. ASTM E562-19 (2019) Standard Test Method for Determining Volume Fraction by Systematic Manual Point Count, ASTM International, West Conshohocken, PA. https://doi.org/10.1520/E0562-19.

76. Tugrul, A.; Gurpinar, O. (1997) The effect of chemical weathering on the engineering properties of eocene basalts in northeastern Turkey. Environ. Eng. Geosci. 2, 225-234. https://doi.org/10.2113/gseegeosci.III.2.225.

77. Le Maitre, R. W. (2002) Igneous rocks: a classification and glossary of terms recommendations of the international union of geological sciences subcommission on the systematics of igneous rocks. Cambridge University Press, (2002). https://doi.org/10.1017/CBO9780511535581.

78. Irvine, T.N.; Baragar, W.R.A. (1971) A gide to the chemical classification of the common volcanic rocks. Can. J. Earth. Sci. 8 [5], 528-548. https://doi.org/10.1139/e71-055.

79. Raymond, L. (2002). Petrology: The Study of Igneous, Sedimentary, and Metamorphic Rocks, 2nd edition, McGraw-Hill Education - Europe. (2002).

80. ISO 14689-1. (2003) International Standard Organization. Geotechnical Uniaxial compressive investigation and testing. Identification and classification of rock. Part 1: identification and description. Geneva: International organization standardization. 1-16.

81. Deere, D.U.; Miller, R.P. (1966) Engineering classification and index properties for intact rock. Tech. Report. Air Force Weapons Lab., New Mexico. No. AFWL-TR-65-116.

82. Shalabi, F.I.; Cording, E.J.; Al-Hattamleh, O.H. (2007) Estimation of rock engineering properties using hardness tests. Eng. Geol. 90 [3-4], 138-147. https://doi.org/10.1016/j. enggeo.2006.12.006.

83. Khandelwal, M. (2013) Correlating P-wave velocity with the physico-mechanical properties of different rocks. Pure. Appl. Geophys. 170, 507-514. https://doi.org/10.1007/ s00024-012-0556-7.

84. Aldeeky, H.; Al Hattamleh, O. (2018) Prediction of engineering properties of basalt rock in Jordan using ultrasonic pulse velocity test. Geotech. Geol. Eng. 36, 3511-3525, https://doi.org/10.1007/s10706-018-0551-6.

85. Mahdiyar, A.; Armaghani, D.J.; Marto, A.; Nilashi, M.; Ismail, S. (2018) Rock tensile strength prediction using empirical and soft computing approaches. Bull. Eng. Geol. Environ. 78, 4519-4531. https://doi.org/10.1007/ s10064-018-1405-4.

86. Rezaei, M. (2018) Indirect measurement of the elastic modulus of intact rocks using the Mamdani fuzzy inference system. Measur. 129, 319-331, https://doi.org/10.1016/j. measurement.2018.07.047. 